\title{
Investigation of Mutagenic Effects of Pea Green and Anti-carcinogenic Effects of Several Plants Extracts in Drosophila Melanogaster Using Wing Spot
}

\author{
Aylin Yilmaz Cetinkaya ${ }^{1 *} \quad$ Selcuk Yurtsever ${ }^{2}$ \\ 1.Keşan Hakk1 Yörük School of Health, Turkey Trakya University, Hersekzade Campus 22800 Keşan Edirne, \\ Turkey \\ 2.Department of Biology, Science Faculty, Turkey Trakya University, Balkan Campus 22030 Edirne, Turkey
}

\begin{abstract}
In the present study, Pea green (E 102 - E 133) is coloring additive for its genotoxic effects and expected antigenotoxic effects of several plant extracts; Hypericum perforatum L., Silybum marianum (L.) Gaertn., Lavandula stoechas L. against the food coloring were examined using Wing spot test on Drosophila melonagaster in the laboratory experiments. The Drosophila lar-vae were chronically fed in food mediums where Pea green at $25 \mathrm{~g} / \mathrm{L}, 50 \mathrm{~g} / \mathrm{L}$, and $75 \mathrm{~g} / \mathrm{L}$ concen-trations were experimentally applied. The results showed that Pea green has highly significant results at different exposure concentrations in trans-heterozygous flies $(\mathrm{mwh} / \mathrm{flr} 3)$ and balanc-er-heterozygous flies (mwh/TM3) for inducing the numbers of mutant wing spots compared to control groups (Chi-Square test; $\mathrm{df}=3, \mathrm{P}<0.001$ ). Thus, it seemed that the food coloring is a highly mutagenic agent on Drosophila melanogaster in the laboratory conditions. On the other hand, the concentrations of Pea green were used together different plant extracts at $100 \mathrm{~g} / \mathrm{L}$ concentra-tion in the mediums. The numbers of mutant wing spots were compared to control groups showed that the three plant extracts have not effects to reduce the mutant spots in mwh/flr3 and mwh/TM3 flies and thus they have not antigenotoxic effects used experimental treatments (Kruskal-Wallis test; $\mathrm{df}=2, \mathrm{P}>0.05$ )
\end{abstract}

Keywords:Genotoxicity, antigenotoxicity; Pea green; Hypericum perforatum L.; Silybum marianum (L.) Gaertn., Lavandula stoechas L.; Drosophila melanogaster Meigen; Wing spot test

DOI: $10.7176 / \mathrm{JHMN} / 95-05$

Publication date: November $30^{\text {th }} 2021$

\section{Introduction}

With the new technologies used in the food industry and the increasing variety of products, the interest in readymade foods is increasing day-by-day with consumer demand(AKBULUT 2011). Food additives are frequently found in ready-to-eat foods and are among the potentially important genotoxic agents(Vural 2005; Alkan and Anlas 2015). In addition to the nutritional values of consumed food, its safety and effects on human health are nowadays widely discussed(Alkan and Anlas 2015).

Food coloring agents can create allergic reactions, skin rashes, asthma, hyperactivity and concentration disorder, hypersensitivity, migraine, preterm delivery, salicylate sensitivity and cancer when not used within legal restrictions (Yentür 1996; Maier et al. 2010).

With genotoxicity tests and epidemiological studies on Drosophila, mouse, rat, and bacteria, when not used within the limits specified in regulations, the synthetic food colorings have been reported to be carcinogenic when used in order to imitate the high quality (Yentür 1996; Sarıkaya 2010). It has been determined that the level of food colorings used in studies on this subject in our country is well above the statute limits and may have harmful effects in terms of public health(Yentür 1996; Topsoy 1990; Yaman 1996).

Pea green used in the present study was preferred because, in the literature, there are very few scientific studies similar to the subject of the present research. There is no study carried out on Pea green in Drosophila by using Wing spot test. There are few studies carried out on Drosophila regarding the genotoxicity of the food coloring. In addition, the plant extracts, widely used among the public and thought to eliminate mutagenic effects, used in the present study was preferred because, in the literature, there is no study carried out on the plant extracts in Drosophila by using Wing spot test. In Drosophila, while there are few scientific studies on the antigenotoxicity of Hypericum perforatum L., there is no study carried out on Silybum marianum (L.) Gaertn. and Lavandula stoechas L.

Using Wing spot test on D. melanogaster Meigen's mwh and flr3 lines, the present research was conducted in order to determine whether Pea green at $25 \mathrm{~g} / \mathrm{L}, 50 \mathrm{~g} / \mathrm{L}, 75 \mathrm{~g} / \mathrm{L}$ concentrations have a detrimental effect, Hypericum perforatum L., Silybum marianum (L.) Gaertn. and Lavandula stoechas L. at $100 \mathrm{~g} / \mathrm{L}$ concentration be successful in reducing the genotoxic effect of the coloring or not. 


\section{Materials and Methods}

\subsection{Culture of Drosophila Lines}

D. melanogaster Meigen lines used in the study were obtained from Trakya University and Akdeniz University, Science Faculty, Biology Department. Drosophila flies were cultured in an incubator where optimum living conditions $\left(25 \pm 1{ }^{\circ} \mathrm{C}\right.$ and $40-60 \%$ relative humidity) were provided and adjusted to 12-hour light and 12-hour dark time period.

\subsection{Creation of Experimental Groups}

In determination the mutagenic and/or recombinogenic effects of Pea green and antigenotoxic effects of the plant extracts against the coloring in D. melanogaster Meigen lines SMART developed by(Graf et al. 1984) was used.

\subsection{Genetic Structure of Drosophila Mutant Strains}

In Drosophila Wing spot test, the mwh, flr3 and BdS (beader-serrate) marker genes on the third largest chromosome of Drosophila are used. In Drosophila Wing spot test, flr3/TM3, BdS virgin females and mwh/mwh males are used for normal metabolic activity cross(Lindsley and Grell 1968; Lindsley and Zimm 2012; GarciaBellido and Dapena 1974).

Experiments of the application groups consisting of experimental, treatment and control groups in the study were conducted simultaneously. Distilled water was used in the negative control group and EMS (Kasımoğlu 2016) is stated in the literature that it has a mutagenic effect, was used at $1 \mathrm{mM}$ concentration in the positive control group. The food coloring and the plant extracts used in the application groups were dissolved in distilled water. Pea green at $25 \mathrm{~g} / \mathrm{L}, 50 \mathrm{~g} / \mathrm{L}$ and $75 \mathrm{~g} / \mathrm{L}$ concentrations in the experimental group and Hypericum perforatum L., Silybum marianum (L.) Gaertn. and Lavandula stoechas L. at $100 \mathrm{~g} / \mathrm{L}$ concentration with the concentrations of the coloring were used for Drosophila larvae at $72 \pm 4$ hours.

D. melanogaster Meigen lines were fed with a standard Drosophila medium when kept in stock and in a cross bottle to perform fertilization and embryogenesis to obtain heterozygous larvae. Drosophila instant medium was used for Drosophila larvae at $72 \pm 4$ hours in the experimental, treatment and control groups. Drosophila instant medium and the food coloring and the plant extracts used in the study were purchased commercially. Drosophila instant medium was obtained from Carolina Biological Supply Company. Pea green was from Roha JJT Group Company. Hypericum perforatum L. (St. John's wort) and Silybum marianum (L.) Gaertn. (milk thistle) were from Solgar and Lavandula stoechas L. (topped lavender) was from Herbal Pharm and EMS was obtained from Sigma Aldrich GmbH.

\subsection{Applications of Experimental Groups}

Larvae in groups of 100 were left into falcon tubes where $1.5 \mathrm{~g}$ of Drosophila instant medium wetted with $5 \mathrm{ml}$ of solutions containing at $25 \mathrm{~g} / \mathrm{L}, 50 \mathrm{~g} / \mathrm{L}$ and $75 \mathrm{~g} / \mathrm{L}$ concentrations of Pea green and/or the plant extracts at 100 $\mathrm{g} / \mathrm{L}$ concentration. While the wing edges of the adult flies developed from trans-heterozygous larvae (mwh/flr3) in each concentration of application groups have normal structure, the wing edges of the balancer-heterozygous flies (mwh/TM3) are in the form of serrate. In evaluation, 40 wings were used for each concentration in all application groups. Slides of normal and serrate wings were examined using a light microscope under $40 \times 10$ magnification to detect the presence of mutant clones(Kaya 2000). Classification of types were according to mutant clones: Small single spots containing of $1-2 \mathrm{mwh}$, large single spots containing $\geq 3 \mathrm{mwh}$ or $\geq 4$ flr 3 and twin spots containing adjacent mwh and flr3 cells(Graf et al. 1984).

\subsection{Statistical Analysis}

Minitab package program was used in the statistical evaluation of the study results. In the analysis of the study data, it was investigated whether the total numbers of mutant spots in the wings of the flies in the positive and negative control groups was statistically different with the Chi-Square test $(\mathrm{df}=1)$. Chi-Square test $(\mathrm{df}=3)$ was used in the analyzes where the total numbers of mutant spots in the wings of the flies in experimental and treatment groups were compared separately with those of the flies in the positive and negative control groups. The total numbers of mutant spots in the wings of the flies in experimental and treatment groups were compared with each other and whether there was a statistical difference was determined by the Chi-Square test $(\mathrm{df}=2)$.

Possible differences between the average of the total numbers of wing mutant spots of flies grown in experimental and treatment groups were compared with Non-Parametric Kruskal-Wallis test ( $\mathrm{df}=2$ ).

The average of the total numbers of mutant spots in the normal and serrate wings of the flies in all experimental groups were compared with the Mann-Whitney U test.

In all evaluation, the total numbers of wing mutant spots obtained from the study and presented as $\mathrm{Fr}$ (Frequency) values and the differences below $\mathrm{P}<0.05$ were considered to be statistically significant. 


\section{Results}

Table 1. Mutant clones in mwh/flr3 wings obtained from experimental group, treatment group, positive and negative control groups

\begin{tabular}{|c|c|c|c|c|c|c|c|c|c|c|c|c|}
\hline \multirow[t]{2}{*}{$\begin{array}{c}\text { Application } \\
\text { groups / } \\
\text { Concentration }(\mathrm{g} / \mathrm{L})\end{array}$} & \multirow[t]{2}{*}{$\begin{array}{c}\text { Number } \\
\text { of } \\
\text { wings }\end{array}$} & \multicolumn{2}{|c|}{$\begin{array}{c}\text { Small single } \\
\text { spots } \\
(1-2 \text { cell })\end{array}$} & \multicolumn{2}{|c|}{\begin{tabular}{|c|} 
Large single \\
spots \\
$(>2$ cell $)$
\end{tabular}} & \multicolumn{2}{|c|}{ Twin spots } & \multicolumn{2}{|c|}{$\begin{array}{l}\text { Total } \\
\text { mwh } \\
\text { spots }\end{array}$} & \multicolumn{3}{|c|}{ Total spots $\mathrm{X}^{2}$} \\
\hline & & No & Fr & No & $\mathrm{Fr}$ & No & $\mathrm{Fr}$ & No & $\mathrm{Fr}$ & No & $\mathrm{Fr}$ & \\
\hline Distilled water & 40 & 3 & $(0.08)$ & 5 & $(0.13)$ & 4 & $(0.13)$ & 3 & $(0.08)$ & 12 & $(0.30)$ & \\
\hline $1 \mathrm{mM}$ EMS & 40 & 49 & $(1.23)$ & 130 & $(3.25)$ & 68 & $(1.70)$ & 99 & $(2.48)$ & 247 & $(6.18)$ & $\mathrm{a}^{* * *}$ \\
\hline 25 Pea green & 40 & 1 & $(0.03)$ & 40 & $(1.00)$ & 0 & $(0.00)$ & 1 & $(0.03)$ & 41 & $(1.03)$ & $\mathrm{a}^{* * *} \quad \mathrm{~b}^{* * *}$ \\
\hline 50 Pea green & 40 & 1 & $(0.03)$ & 57 & $(1.43)$ & 0 & $(0.00)$ & 1 & $(0.03)$ & 58 & $(1.45)$ & $\mathrm{a} * * * \mathrm{~b}^{* * *}$ \\
\hline 75 Pea green & 40 & 3 & $(0.08)$ & 59 & $(1.48)$ & 0 & $(0.00)$ & 4 & $(0.10)$ & 62 & $(1.55)$ & $\mathrm{a} * * * \quad \mathrm{~b} * * *$ \\
\hline $\begin{array}{l}25 \text { Pea green- } H \text {. } \\
\text { perforatum }\end{array}$ & 40 & 2 & $(0.05)$ & 51 & $(1.28)$ & 0 & $(0.00)$ & 2 & $(0.05)$ & 53 & $(1.33)$ & $a^{* * *} \quad b^{* * *}$ \\
\hline $\begin{array}{l}50 \text { Pea green- } H \text {. } \\
\text { perforatum }\end{array}$ & 40 & 3 & $(0.08)$ & 46 & $(1.15)$ & 0 & $(0.00)$ & 3 & $(0.08)$ & 49 & $(1.23)$ & $\mathrm{a}^{* * *} \mathrm{~b}^{* * *}$ \\
\hline $\begin{array}{l}75 \text { Pea green- } H \text {. } \\
\text { perforatum }\end{array}$ & 40 & 3 & $(0.08)$ & 59 & $(1.48)$ & 0 & $(0.00)$ & 5 & $(0.13)$ & 62 & $(1.55)$ & $\mathrm{a}^{* * *} \mathrm{~b}^{* * *}$ \\
\hline $\begin{array}{l}25 \text { Pea green- } S \text {. } \\
\text { marianum }\end{array}$ & 40 & 6 & $(0.15)$ & 31 & $(0.78)$ & 2 & $(0.05)$ & 12 & $(0.30)$ & 39 & $(0.98)$ & $\mathrm{a} * * * \mathrm{~b}^{* * *}$ \\
\hline $\begin{array}{l}50 \text { Pea green- } S \text {. } \\
\text { marianum }\end{array}$ & 40 & 6 & $(0.15)$ & 31 & $(0.78)$ & 0 & $(0.00)$ & 7 & $(0.18)$ & 37 & $(0.93)$ & $\mathrm{a} * * * \mathrm{~b}^{* * *}$ \\
\hline $\begin{array}{l}75 \text { Pea green- } S \text {. } \\
\text { marianum }\end{array}$ & 40 & 2 & $(0.05)$ & 45 & $(1.13)$ & 2 & $(0.05)$ & 5 & $(0.13)$ & 49 & $(1.23)$ & $\mathrm{a} * * * \quad \mathrm{~b} * * *$ \\
\hline $\begin{array}{l}25 \text { Pea green- } L \text {. } \\
\text { stoechas }\end{array}$ & 40 & 0 & $(0.00)$ & 27 & $(0.68)$ & 0 & $(0.00)$ & 0 & $(0.00)$ & 27 & $(0.68)$ & $\mathrm{a}^{* * *} \mathrm{~b} * * * \mathrm{c} * *$ \\
\hline $\begin{array}{l}50 \text { Pea green- } L \text {. } \\
\text { stoechas }\end{array}$ & 40 & 4 & $(0.13)$ & 47 & $(1.18)$ & 1 & $(0.03)$ & 6 & $(0.15)$ & 52 & $(1.30)$ & $\mathrm{a} * * * \mathrm{~b}^{* * *} \mathrm{c} * *$ \\
\hline $\begin{array}{l}75 \text { Pea green- } L \text {. } \\
\text { stoechas }\end{array}$ & 40 & 2 & $(0.05)$ & 56 & $(1.40)$ & 0 & $(0.00)$ & 3 & $(0.08)$ & 58 & $(1.45)$ & $\mathrm{a} * * * \mathrm{~b} * * * \mathrm{c} * *$ \\
\hline $\mathrm{H}, \mathrm{P}^{\#}$ & & & & & & & & & & & & $3.77,>0.05$ \\
\hline $\mathrm{P}^{\S}$ & & & & & & & & & & & & $<0.001$ \\
\hline
\end{tabular}

No: Number of mutant clones, Fr: Frequency; \#: It was evaluated by Kruskal-Wallis test;

$\S$ : It was evaluated by Mann-Whitney U test; X2: In evaluation with Chi-Square test; a: with Distilled water, b: with EMS, c: with Pea green; *: $\mathrm{P}<0.05$, **: $\mathrm{P}<0.01$, ***: $\mathrm{P}<0.001$

Table 2. Mutant clones in mwh/TM3 wings obtained from experimental group, treatment group, positive and negative control groups

\begin{tabular}{|c|c|c|c|c|c|c|c|c|c|c|c|c|}
\hline \multirow[t]{2}{*}{$\begin{array}{c}\text { Application } \\
\text { groups / } \\
\text { Concentration }(\mathrm{g} / \mathrm{L}) \\
\end{array}$} & \multirow[t]{2}{*}{$\begin{array}{l}\text { Number } \\
\text { of wings }\end{array}$} & \multicolumn{2}{|c|}{\begin{tabular}{|c|} 
Small \\
single spots \\
$(1-2$ cell $)$
\end{tabular}} & \multicolumn{2}{|c|}{\begin{tabular}{|c|} 
Large single \\
spots \\
$(>2$ cell $)$
\end{tabular}} & \multicolumn{2}{|c|}{ Twin spots } & \multicolumn{2}{|c|}{$\begin{array}{l}\text { Total mwh } \\
\text { spots }\end{array}$} & \multicolumn{3}{|c|}{ Total spots $\mathrm{X}^{2}$} \\
\hline & & No & Fr & No & $\mathrm{Fr}$ & No & $\mathrm{Fr}$ & No & $\mathrm{Fr}$ & No & $\mathrm{Fr}$ & \\
\hline Distilled water & 40 & 1 & $(0.03)$ & 6 & $(0.15)$ & 0 & $(0.00)$ & 1 & $(0.03)$ & 7 & $(0.18)$ & \\
\hline $1 \mathrm{mM}$ EMS & 40 & 22 & $(0.55)$ & 66 & $(1.65)$ & 0 & $(0.00)$ & 71 & (1.78) & 88 & $(2.20)$ & $\mathrm{a}^{* * *}$ \\
\hline 25 Pea green & 40 & 4 & $(0.03)$ & 32 & $(0.80)$ & 0 & $(0.00)$ & 4 & $(0.10)$ & 36 & $(0.90)$ & $\mathrm{a}^{* * *} \mathrm{~b}^{* * * *}$ \\
\hline 50 Pea green & 40 & 1 & $(0.00)$ & 31 & $(0.78)$ & 0 & $(0.00)$ & 1 & $(0.03)$ & 32 & $(0.80)$ & $a^{* * *} b^{* * * *}$ \\
\hline 75 Pea green & 40 & 5 & $(0.08)$ & 38 & $(0.95)$ & 0 & $(0.00)$ & 5 & $(0.13)$ & 43 & $(1.08)$ & $a^{* * *} b^{* * *}$ \\
\hline $\begin{array}{l}25 \text { Pea green- } H \text {. } \\
\text { perforatum }\end{array}$ & 40 & 1 & $(0.05)$ & 23 & $(0.58)$ & 0 & $(0.00)$ & 1 & $(0.03)$ & 24 & $(0.60)$ & $a^{* * *} \quad b^{* * *}$ \\
\hline $\begin{array}{l}50 \text { Pea green- } H \text {. } \\
\text { perforatum }\end{array}$ & 40 & 0 & $(0.13)$ & 28 & $(0.70)$ & 0 & $(0.00)$ & 0 & $(0.00)$ & 28 & $(0.70)$ & $a^{* * *} b^{* * *}$ \\
\hline $\begin{array}{l}75 \text { Pea green- } H \text {. } \\
\text { perforatum }\end{array}$ & 40 & 4 & $(0.03)$ & 31 & $(0.78)$ & 0 & $(0.00)$ & 5 & $(0.13)$ & 35 & $(0.88)$ & $a^{* * *} \quad b^{* * *}$ \\
\hline $\begin{array}{l}25 \text { Pea green- } S \text {. } \\
\text { marianum }\end{array}$ & 40 & 1 & $(0.00)$ & 30 & $(0.75)$ & 0 & $(0.00)$ & 1 & $(0.03)$ & 31 & $(0.78)$ & $a^{* * *} b^{* * *}$ \\
\hline $\begin{array}{l}50 \text { Pea. green- } S \text {. } \\
\text { marianum }\end{array}$ & 40 & 3 & $(0.03)$ & 30 & $(0.75)$ & 0 & $(0.00)$ & 3 & $(0.08)$ & 33 & $(0.83)$ & $a^{* * *} \quad b^{* * *}$ \\
\hline
\end{tabular}




\begin{tabular}{|c|c|c|c|c|c|c|c|c|c|c|c|c|}
\hline $\begin{array}{c}\text { Application } \\
\text { groups / } \\
\text { Concentration }(\mathrm{g} / \mathrm{L})\end{array}$ & $\begin{array}{l}\text { Number } \\
\text { of wings }\end{array}$ & sing & $\begin{array}{l}\text { nall } \\
\text { e spots } \\
\text { cell) }\end{array}$ & $\begin{array}{r}\text { Larg } \\
\mathrm{s} \\
(>2\end{array}$ & $\begin{array}{l}\text { single } \\
\text { ots } \\
\text { cell) }\end{array}$ & Tw & spots & & $\begin{array}{l}1 \mathrm{mwh} \\
\text { ots }\end{array}$ & & Total s & pots $X^{2}$ \\
\hline $\begin{array}{l}75 \text { Pea green- } S \\
\text { marianum }\end{array}$ & 40 & 0 & $(0.03)$ & 26 & $(0.65)$ & 0 & $(0.00)$ & 0 & $(0.00)$ & 26 & $(0.65)$ & $a^{* * *} b^{* * *}$ \\
\hline 25 Pea green-L. stoechas & 40 & 1 & $(0.00)$ & 23 & $(0.58)$ & 0 & $(0.00)$ & 3 & $(0.08)$ & 24 & $(0.60)$ & $a^{* * *} b^{* * *}$ \\
\hline 50 Pea green-L. stoechas & 40 & 2 & $(0.03)$ & 24 & $(0.60)$ & 0 & $(0.00)$ & 3 & $(0.08)$ & 27 & $(0.68)$ & $a^{* * *} b^{* * *}$ \\
\hline 75 Pea green-L. stoechas & 40 & 2 & $(0.00)$ & 33 & $(0.83)$ & 0 & $(0.00)$ & 2 & $(0.05)$ & 35 & $(0.88)$ & $a^{* * *} b^{* * *}$ \\
\hline $\mathrm{H}, \mathrm{P}^{\#}$ & & & & & & & & & & & & $3.85,>0.05$ \\
\hline $\mathrm{P}^{\S}$ & & & & & & & & & & & & $<0.001$ \\
\hline
\end{tabular}

No: Number of clones, Fr: Frequency, \#: It was evaluated by Kruskal-Wallis test;

$\S$ : It was evaluated by Mann-Whitney U test; X2: In evaluation with Chi-Square test; a: with Distilled water, b: with EMS, c: with Pea green, *: $\mathrm{P}<0.05, * *: \mathrm{P}<0.01, * * *$ : $\mathrm{P}<0.001$

When the results of the study were evaluated, the total numbers of mutant spots in normal $(X 2=213.22$, $\mathrm{df}=1, \mathrm{P}<0.001)$ wings (in Table 1 ) and serrate $(\mathrm{X} 2=69.06, \mathrm{df}=1, \mathrm{P}<0.001)$ wings (in Table 2 ) of Drosophila flies in the positive control group was found to be much more than those of negative control group.

Wing spot test data obtained from experimental group studies of Pea green were compared with results of positive and negative control groups. The total numbers of mu-tant spots in the normal wings (in Table 1) and serrate wings (in Table 2) of the Drosophi-la flies grown in the containing with $25 \mathrm{~g} / \mathrm{L}, 50 \mathrm{~g} / \mathrm{L}$ and $75 \mathrm{~g} / \mathrm{L}$ concentrations of the Pea green is higher than those grown in the medium prepared with distilled water (normal wings: $\mathrm{X} 2=35.85, \mathrm{df}=3, \mathrm{P}<0.001$; serrate wings: $\mathrm{X} 2=24.98, \mathrm{df}=3, \mathrm{P}<0.001$ ) but it was found to be less than those grown in medium with EMS addition (normal wings: $\mathrm{X} 2=277.27, \mathrm{df}=3, \mathrm{P}<0.001$; serrate wings: $\mathrm{X} 2=40.45$, $\mathrm{df}=3$, $\mathrm{P}<0.001)$.

The total numbers of mutant spots in the normal and serrate wings of the Drosophila flies grown in the mediums having three different concentrations of Pea green with Hy-pericum perforatum L. at $100 \mathrm{~g} / \mathrm{L}$ concentration is higher than grown that of the flies in the medium prepared with distilled water (normal wings in Table 1: $\mathrm{X} 2=33.04, \mathrm{df}=3, \mathrm{P}<0.001$; serrate wings in Table 2: $\mathrm{X} 2=18.08, \mathrm{df}=3, \mathrm{P}<0.001$ ) but it was found to be less than those grown in medium added to EMS (normal wings in Table 1: $\mathrm{X} 2=270.87, \mathrm{df}=3, \mathrm{P}<0.001$; ser-rate wings in Table 2: $\mathrm{X} 2=61.09, \mathrm{df}=3, \mathrm{P}<0.001)$.

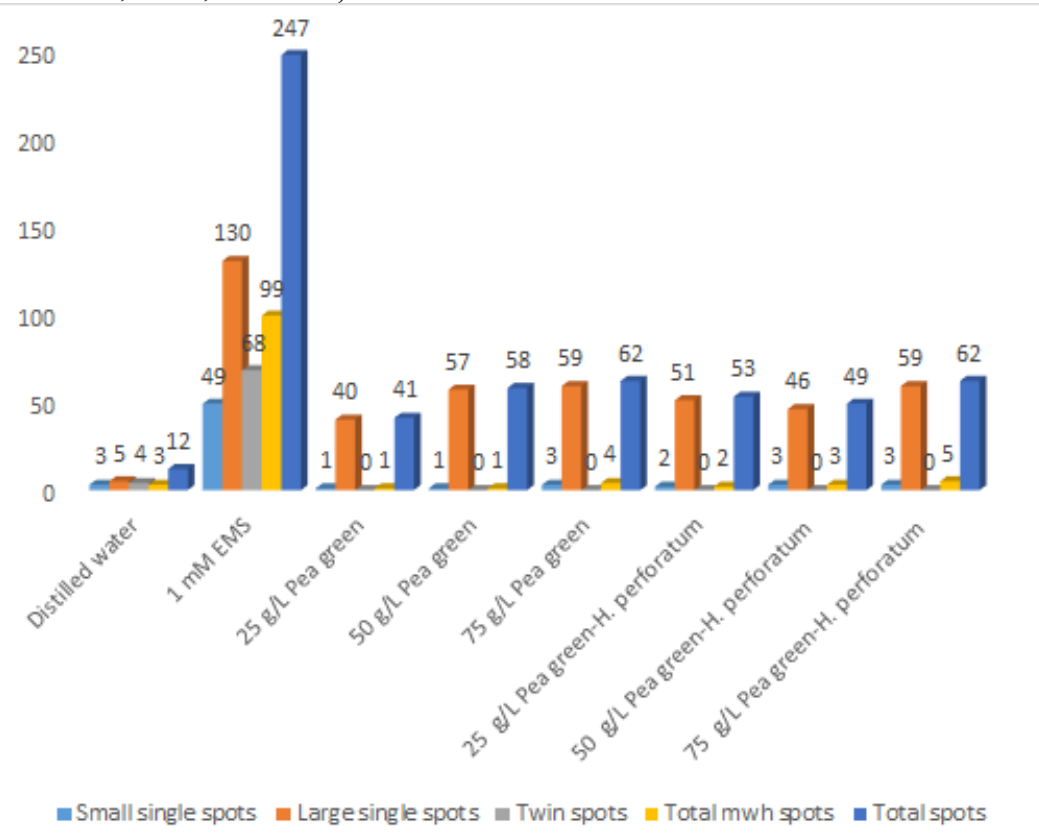

Figure 1. shows classification of mutant clones with the normal wings of the Drosophila flies in the experimental group, treatment group with Hypericum perforatum L. and the positive with negative control groups. 


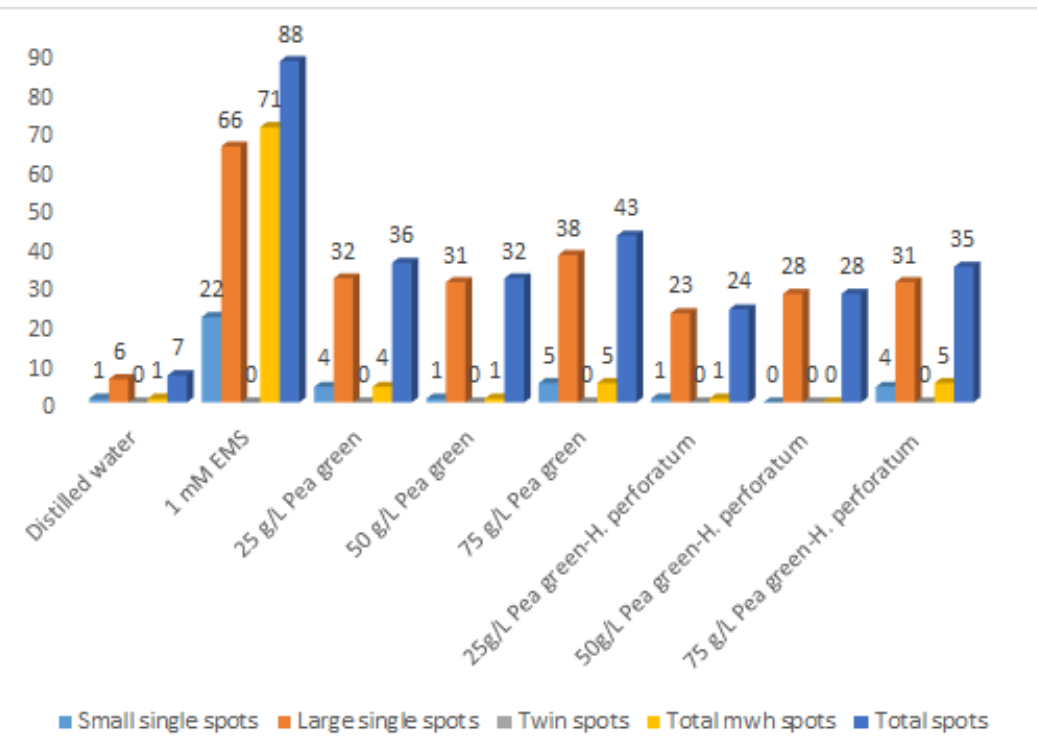

Figure 2. shows classification of mutant clones with the serrate wings of the Drosophila flies in the experimental group, treatment group with Hypericum perforatum L. and the positive with negative control groups.

The total numbers of mutant spots in the normal and serrate wings of the Drosophila flies grown in the mediums with three different concentrations of Pea green and $100 \mathrm{~g} / \mathrm{L}$ concentration of Silybum marianum (L.) Gaertn are more than that of the flies grown in medium containing distilled water (normal wings in Table 1: $\mathrm{X} 2=21.68, \mathrm{df}=3, \mathrm{P}<0.001$; serrate wings in Table $2: \mathrm{X} 2=17.43, \mathrm{df}=3, \mathrm{P}<0.001$ ) but it was found to be lower than those grown in medium with EMS (normal wings in Table 1: $\mathrm{X} 2=340.90, \mathrm{df}=3, \mathrm{P}<0.001$; serrate wings in Table 2: $\mathrm{X} 2=57.28, \mathrm{df}=3, \mathrm{P}<0.001$ ).

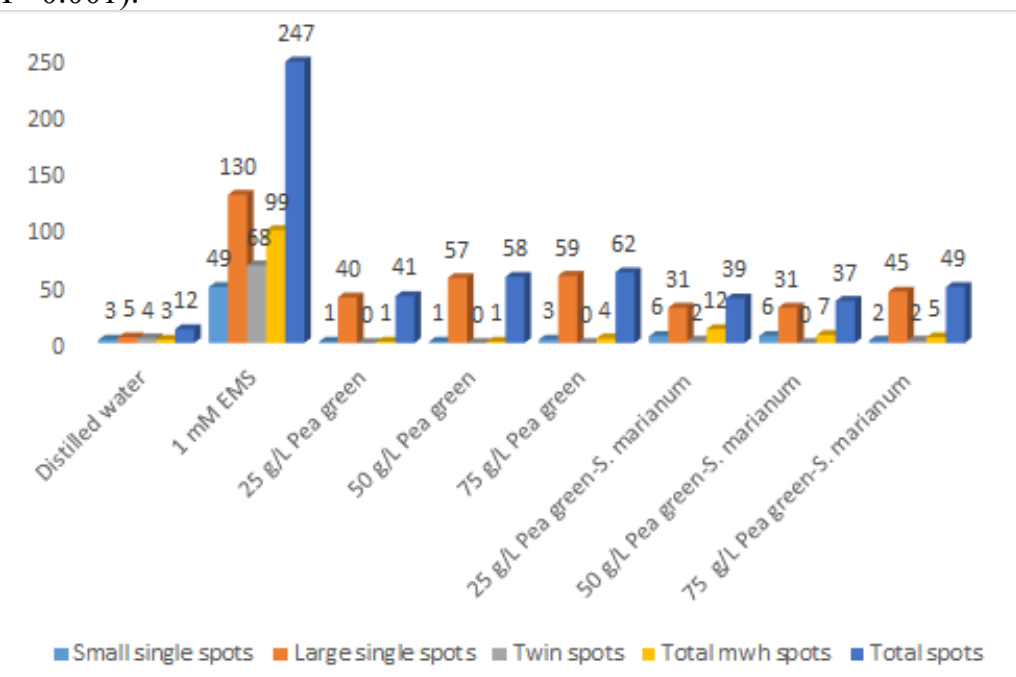

Figure 3. shows classification of mutant clones with the normal wings of the Drosophila flies in the experimental group, treatment group with Silybum marianum (L.) Gaertn. and the positive with negative control groups. 


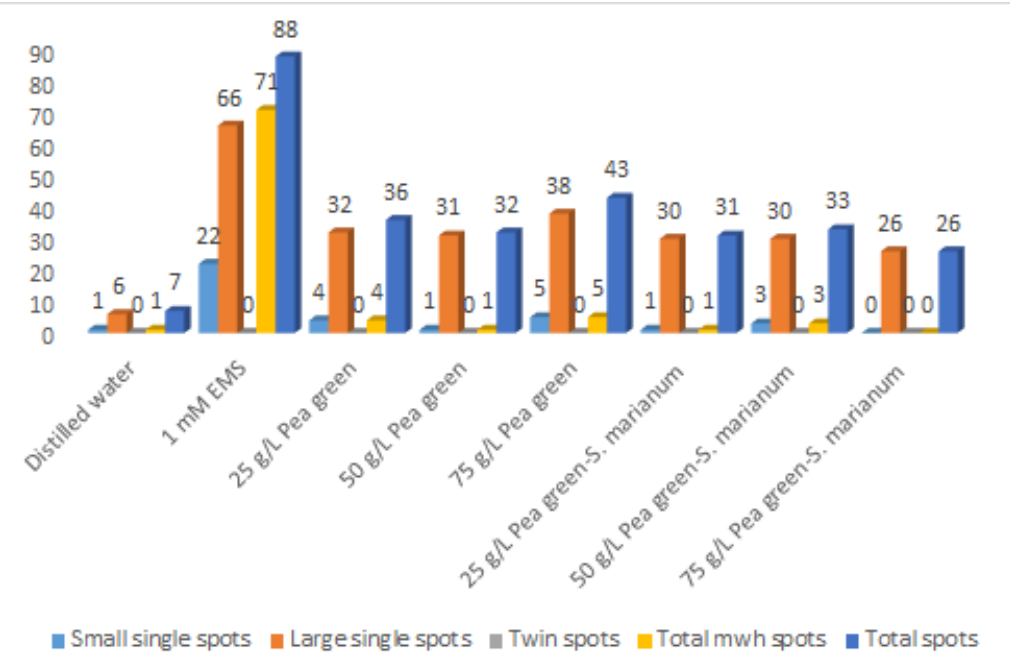

Figure 4. shows classification of mutant clones with the serrate wings of the Drosophila flies in the experimental group, treatment group with Silybum marianum (L.) Gaertn. and the positive with negative control groups.

The total numbers of mutant spots in the normal and serrate wings of the Drosophila flies grown in the mediums having three different concentrations of Pea green with La-vandula stoechas L. at $100 \mathrm{~g} / \mathrm{L}$ concentration are higher than that of the flies grown in the medium prepared with distilled water (normal wing in Table 1: $\mathrm{X} 2=37.33$, $\mathrm{df}=3, \mathrm{P}<0.001$; serrate wing in Table 2: $\mathrm{X} 2=17.92, \mathrm{df}=3, \mathrm{P}<0.001$ ) but it was found to be less than those grown in medium with EMS (normal wing in Table 1: $\mathrm{X} 2=322.31, \mathrm{df}=3, \mathrm{P}<0.001$; serrate wing in Table 2: $\mathrm{X} 2=62.18, \mathrm{df}=3, \mathrm{P}<0.001$ ).

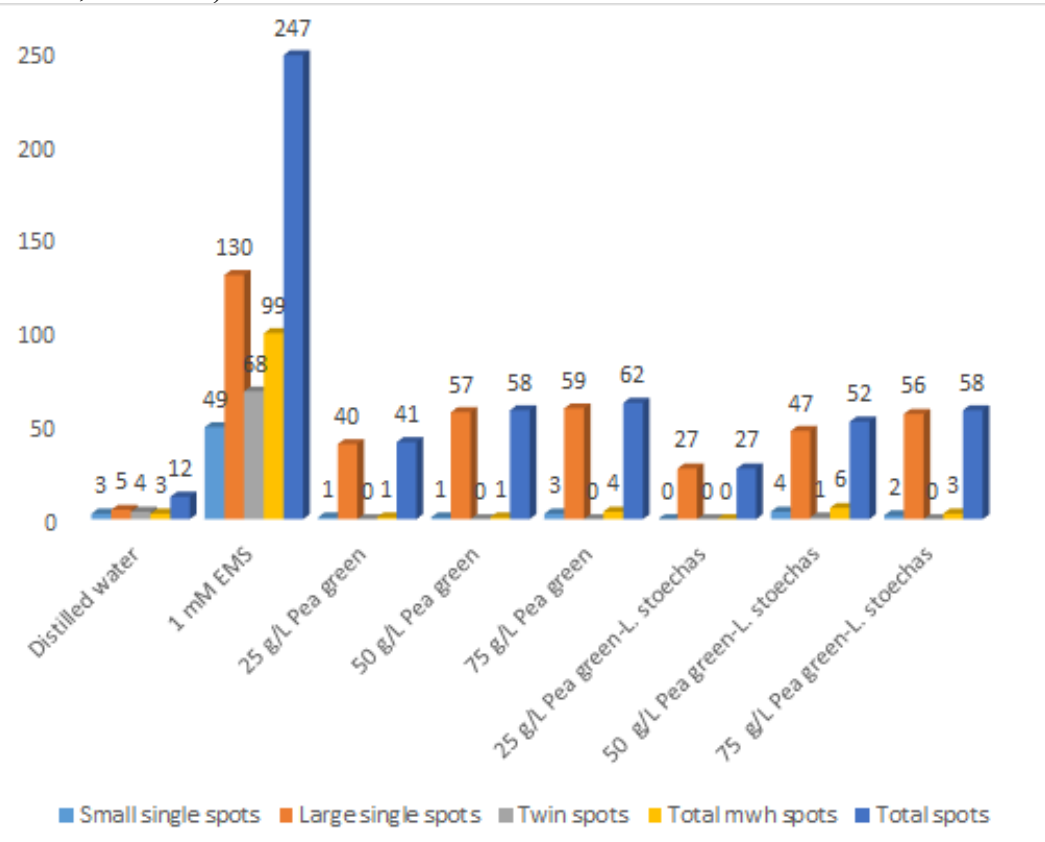

Figure 5. shows classification of mutant clones with the normal wings of the Drosophila flies in the experimental group, treatment group with Lavandula stoechas L. and the positive and negative control groups. 


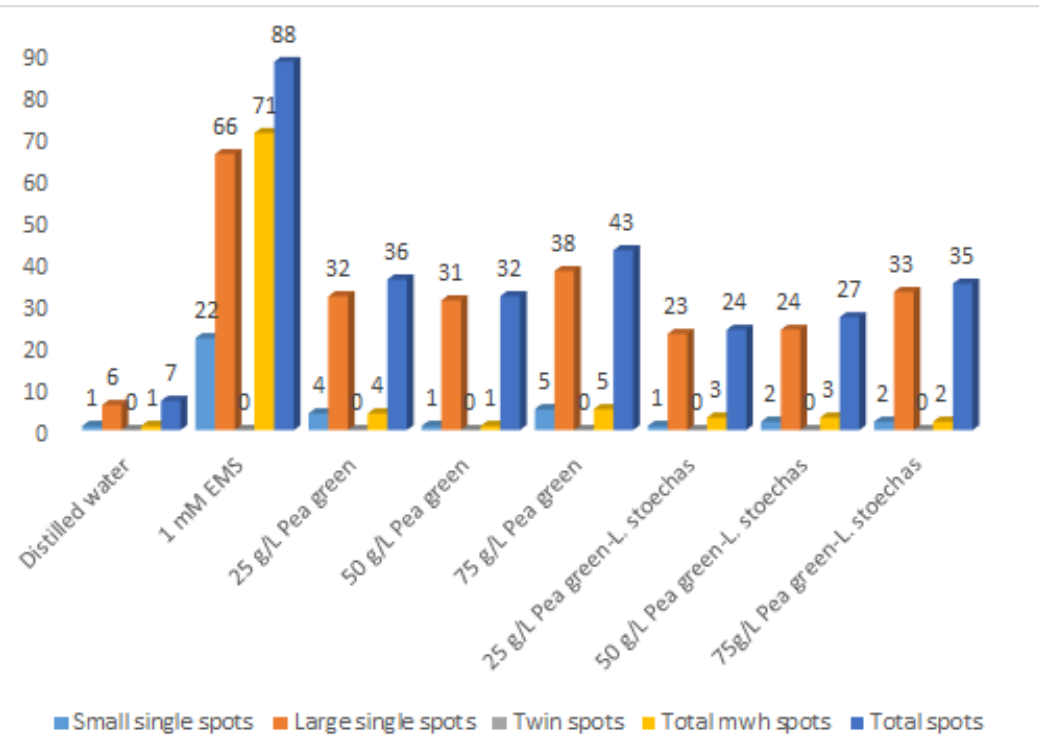

Figure 6. shows classification of mutant clones with the serrate wings of the Drosophila flies in the experimental group, treatment group with Lavandula stoechas L. and the positive and negative control groups.

Statistical analysis shows that total numbers of mutant spots in the wings of the flies in all experimental and treatment groups increased gradually depending on the concen-tration of Pea green.

While numerical differences between the total numbers of mutant spots in the normal wings of the flies are evaluated in the experimental group with three different concentra-tions of Pea green $4 \mathrm{R}(\mathrm{X} 2=4.63 \mathrm{df}=2$, $\mathrm{P}>0.05)$, in treatment group in which three different concentrations of Pea green and Hypericum perforatum L. $(\mathrm{X} 2=1.62 \mathrm{df}=2, \mathrm{P}>0.05)$ and in treatment group in which three different concentrations of Pea green and Silybum maria-num (L.) Gaertn $(\mathrm{X} 2=1.98 \mathrm{df}=2, \mathrm{P}>0.05)$ have not statistically significant, in treatment group in which three different concentrations of Pea green and Lavandula stoechas L. $(\mathrm{X} 2=11.83$, df $=2, \mathrm{P}<0.01)$ they have statistical significance. In other words, the total num-bers of mutant wing spots within themselves of the treatment groups in which Pea green and the plant extracts does not significant differences. Furthermore, statistical differences of the total numbers of mutant spots in the serrate wings of the flies are not significant depend on the concentration in the experimental group $(\mathrm{X} 2=1.67 \mathrm{df}=2, \mathrm{P}>0.05)$, in the treat-ment group in which Pea green and seperately Hypericum perforatum L. $(\mathrm{X} 2=2.13 \mathrm{df}=2, \mathrm{P}>0.05)$, in the treatment group with Pea green and Silybum marianum (L.) Gaertn $(\mathrm{X} 2=0.86 \mathrm{df}=2, \mathrm{P}>0.05)$ and in the treatment group with Pea green and Lavandula stoechas L. $(\mathrm{X} 2=2.25, \mathrm{df}=2, \mathrm{P}>0.05)$.

When average numbers of mutant spots in normal wings $(\mathrm{H}=3.77 ; \mathrm{df}=3, \mathrm{P}>0.05)$ and serrate wings $(\mathrm{H}=3.85$; $\mathrm{df}=3, \mathrm{P}>0.05$ ) of flies in the experimental group with three different concentrations of Pea green and in the treatment groups in which three different concen-trations of Pea green were together with separately Hypericum perforatum L., Si-lybum.marianum (L.) Gaertn, Lavandula stoechas L. were compared with each other, it was observed that results found were not different.

Finally, when average of total numbers of mutant spots in the normal and serrate wings of the flies in the experimental and treatment groups were compared with each other, it was revealed to be statistically differences $(\mathrm{P}<0.001)$.

\section{Discussion}

Although the food additives play a significant role in the food industry, their effects on human health constitute an important issue. As a result of the increase in ready-made food consumption together with urbanization, potential health risks occur with the body's exposure to more additives(AKBULUT 2011).

Many studies on human diseases have shown that D. melanogaster Meigen, a down-organized eukaryotic organism, can be used instead of mammals. Because, the bio-logical properties of the imaginal disc cells in Drosophila larvae undergoing proliferation and differentiation to form body parts in the adult stage are similar to many can-cer-sensitive mammalian cells, and more than $60 \%$ of genes identified in human genetic diseases are common with the genes in Drosophila genome. Drosophila is frequently in-cluded as a model organism in Wing spot test.

Wing spot test assay principle is based on loss of heterozygosity in recessive marker genes; mwh and flr3 on the third largest chromosome lead formation of imaginal disc cells in Drosophila heterozygous larvae into mutant wing spots cell by mutation or re-combination that are the results of genotoxic and anti-genotoxic effects induced by chem-icals (Graf et al. 1984). Moreover, this in vivo test method in Drosophila are associated with in 
vivo genotoxicity tests in mammals (Graf et al. 1984; Graf and Würgler 1996).

Wing spot test plays an important role in the present study for examining that geno-toxic damage caused by the food additive and anti-genotoxic effects of the plant extracts on the model organism, D. melanogaster Meigen.

When the present study data are evaluated using Wing spot test, it becomes clear that Pea green has a mutagenic effect in normal and serrate wings of Drosophila flies at stud-ied concentrations. Serrate wings of the fruit flies contain only clones resulting from muta-tion, while mutant clones resulting from both mutation and recombination can be seen in normal wings(Kaya, Yanikoglu, and Marcos 1999; Zordan et al. 1994).

The mutant spots induced in Drosophila flies with Pea green are a result of the geno-toxic activity of this genotoxic agent depend on its concentration. The food coloring agent has a genotoxic effect in the imaginal disc cells that will transform into the wing spot cells during the embryonic development of Drosophila heterozygous larvae and the genotypic changes caused by mutation or recombination in somatic cells also play a role in the for-mation of mutant spots in the wings. The present study result is consistent with the re-searches below, where the toxic effects of Pea green (Tartrazine - E 102 and Brilliant Blue FCF -E 133 combination) are examined. Uysal \& Semerdöken(Uysal H. 2011) re-ported increased toxicity in Oregon R of Drosophila larvae (72 \pm 4 hours) depending on the increase in concentration of Pea green, whereas Semerdoken (Semerdoken 2012) is-sued that Tartrazine increased the mortality rate in Oregon R wild and Vestigial mutant strains of Drosophila larvae at $72 \pm 4$ hours and Uysal et al. (Uysal, Genç, and Ayar 2017) reported that, according to larval mortality and life span, Tartrazine had the highest toxicity in Oregon R wild of D. melanogaster larvae at $72 \pm 4$ hours among other food dyes, Turkoglu et al. (Türkoğlu, Benli, and Şahin 2015) notified that Brilliant Blue FCF caused the biggest decreased in life span of Drosophila melanogaster among other food colorants and Kumar et al. (Parameswara Bushan Kumar 2020) revealed that on exposure to Brilliant Blue, larvae and pre-adult stages were prone to developmental toxicity.

Hypericum perforatum L., Silybum marianum (L.) Gaertn. and Lavandula stoechas L. didn't show reducing or preventive effects on mutations caused by Pea green. When the average of the total numbers of mutant spots on wings of the flies in Pea green treatment and experiment groups were compared with each other, it didn't have any difference.

When the literature is examined, it is seen that there are a few studies about antigen-otoxicity of the plant extracts in D. melanogaster Meigen. It was also given below that sim-ilar antigenotoxitiy studies in various model organisms about the plant extracts evaluated with different test systems.

(Neo A. 2011) reported that Hypericum perforatum L. at 2.5\%, 12.5\% and 50\% concentrations slowed cell death in Drosophila cells by suppressing the expression of denatured proteins. (Handan Uysal 2007) showed that when Hypericum perforatum L. in different concentrations didn't cause elongation of D. melanogaster Meigen F1 progeny trasformation time to adult, increased numbers of off-spring due to increase in concentrations and had highest numbers of offspring at concen-tration of $10 \mathrm{ml} / 100 \mathrm{ml}$. (Branda et al. 2006) published that Hypericum perforatum L. taken with diet was ineffective on leukopenia caused by chemotheropathic drugs on experimental cancer model induced in rats. (Martarelli et al. 2004) notified that while Hypericum perforatum L. prepared in methanol $80 \%$ reduced rate of growth and development of prostate adenocar-cinoma cells in humans, $70 \%$ experimental cancer induced in mice.

(CAN 2014) reported that Silybum marianum (L.) taken with diet at $10 \%$ concentration reduced DNA damage and apoptosis in rats which liver damage induced by carbon tetrachloride. (Zhou et al. 2006) showed that active sub-stances of Silybum marianum (L.) was effective in reducing DNA damage and regulation of cell cycle in rats. (García-Maceira and Mateo 2009) published that cervical and liver cancers in humans are inhibited by Silybum marianum (L.).

(Kulcanay 1998) notified that when oil with leaf and flower ex-tracts of Lavandula stoechas L. evaluated with Salmonella/microsome test, they were mutagenic. (Ayral 1997) reported that while some of essential oil com-pounds in above ground parts of Lavandula stoechas L. had strong cytotoxic and anti-bacterial effects in different cancer cells. (Magro et al. 2006) showed that when one of the antigenotoxic effects of Lavandula stoechas L. tested for fun-gistatic (delaying or inhibiting fungal growth) activity in various mushrooms, the plant extract was ineffective.

Results of the researches above mentioned and these study data are not parallel to each other. Accordingly, the study data show that these plant extracts were ineffective at $100 \mathrm{~g} / \mathrm{L}$ concentration studied as a single dose in protecting Drosophila flies against the genotoxicity of the synthetic food coloring. More basic and clinical studies are need to be determined for effectiveness of the plant extracts. Furthermore, the plant extracts can be used in different concentrations and for longer periods of time. Determining the efficacy and safety of the plant extracts is closely related to the health of today and in the future generations.

It is thought that this study can contribute to scientific researches and similar exper-iments will do later. More scientific studies are required to explain molecular mechanisms and distributions of the genotoxicity of the food coloring used in the study and the anti-genotoxicity of the plant extracts by using in vivo and in vitro test 
systems in/on different model organisms.

Nutrition is one of the most important factors ensuring the continuity of life. Nowa-days, it is seen that people's eating habits significantly differ as a result of the changes in lifestyle and economic development. (AKBULUT 2011). With controlling the synthetic food coloring and the plants extracts consumption public health should be protected.

\section{References}

AKBULUT, Mehmet. 2011. "Food additives: functions and resources." In 1.Ulusal Helal ve Sağllklı Glda Kongresi.

Alkan, FU, and C Anlas. 2015. 'Genotoxicity tests and genotoxic poisons', Turkish Clinics J Vet Sci Pharmacol Toxicol-Special Topics, 1: 69-74.

Ayral, NM. 1997. 'Lavandula stoechas ssp. stoechas bitkisinin uçucu yağının ve uçucu olmayan organik bileşenlerinin incelenmesi ve biyolojik aktivitelerinin belirlenmesi. Marmara Üniversitesi', Fen Bilimleri Enstitüsü Yüksek Lisans Tezi, İstanbul, Türkiye.

Branda, Richard F., Cheryl Powden, Elice M. Brooks, Zafer Yildirim, Shelly J. Naud, and John J. McCormack. 2006. 'Vitamin E but not St. John's wort mitigates leukopenia caused by cancer chemotherapy in rats', Translational Research, 148: 315-24.

CAN, MUHAMMED İSMAİL. 2014. 'Karbon tetraklorür (CCl4) ile karaciğer hasarı oluşturulmuş ratlarda deve dikeni (Silybum marianum L.)'nin kaspaz-3, kaspaz-9, bax, BCL-2 proteinlerinin ekspresyonu ve DNA hasarı üzerine etkisi/The effect of thistle (Silybum marianum L.) on the caspase-3, caspase-9, bax,-2 protein expression and DNA damage in rats with carbon tetrachloride (CCl4)-induced liver damage'.

Garcia-Bellido, A., and J. Dapena. 1974. 'Induction, detection and characterization of cell differentiation mutants inDrosophila', Molecular and General Genetics MGG, 128: 117-30.

García-Maceira, P., and J. Mateo. 2009. 'Silibinin inhibits hypoxia-inducible factor-1 $\alpha$ and mTOR/p70S6K/4EBP1 signalling pathway in human cervical and hepatoma cancer cells: implications for anticancer therapy', Oncogene, 28: 313-24.

Graf, U., F. E. Würgler, A. J. Katz, H. Frei, H. Juon, C. B. Hall, and P. G. Kale. 1984. 'Somatic mutation and recombination test in Drosophila melanogaster', Environmental Mutagenesis, 6: 153-88.

Graf, Ulrich, and Friedrich E. Würgler. 1996. 'The somatic white-ivory eye spot test does not detect the same spectrum of genotoxic events as the wing somatic mutation and recombination test in Drosophila melanogaster', Environmental and Molecular Mutagenesis, 27: 219-26.

Handan Uysal, Ayse Aydan Kara, Omer Faruk Algur, Rahmi Dumlupynar and Mehmet Nuri Aydogan. 2007. ' Recovering Effects of Aqueous Extracts of Some Selected Medical Plants on the Teratogenic Effects During the Development of D. melanogaster. ', Pakistan Journal of Biological Sciences, 10: 1708-12.

Kasımoğlu, C , Uysal, H . 2016. "'Genoprotective Effects of Aqueous Extracts of Rosa Canina L. Fruits on Ethyl Methanesulfonate-Induced DNA Damage in Drosophila Melanogaster" ', Cumhuriyet Üniversitesi Fen Edebiyat Fakültesi Fen Bilimleri Dergisi, 37: 241-47.

Kaya, B. 2000. 'Investigation of mutagenic and recombinogenic effects of some pesticides on Drosophila melanogaster lines', Akdeniz Üniversitesi Fen Bilimleri Enstitüsü Yayınları.

Kaya, Bülent, Atila Yanikoglu, and Ricardo Marcos. 1999. 'Genotoxicity studies on the phenoxyacetates 2,4-D and 4-CPA in the Drosophila wing spot test', Teratogenesis, Carcinogenesis, and Mutagenesis, 19: 305-12.

Kulcanay, I. 1998. 'Lavandula stoechas L. Bitki Ekstre ve Yağının Ames/Salmonella/Mikrozom Test Sistemi ile Mutajenitesinin Araştırılması', Osmangazi Üniversitesi

Lindsley, Dan L, and Ellsworth Herman Grell. 1968. 'Genetic variations of Drosophila melanogaster', 11: 12.

Lindsley, Dan L, and Georgianna G Zimm. 2012. The genome of Drosophila melanogaster (Academic press).

Magro, Ana, Manuela Carolino, Margarida Bastos, and António Mexia. 2006. 'Efficacy of plant extracts against stored products fungi', Revista Iberoamericana de Micología, 23: 176-78.

Maier, Elisabeth, Katharina Kurz, Marcel Jenny, Harald Schennach, Florian Ueberall, and Dietmar Fuchs. 2010. 'Food preservatives sodium benzoate and propionic acid and colorant curcumin suppress Th1-type immune response in vitro', Food and chemical toxicology, 48: 1950-56.

Martarelli, D., B. Martarelli, D. Pediconi, M. I. Nabissi, M. Perfumi, and P. Pompei. 2004. 'Hypericum perforatum methanolic extract inhibits growth of human prostatic carcinoma cell line orthotopically implanted in nude mice', Cancer Letters, 210: 27-33.

Neo A., Tan D., Ferguson A., Morris C. 2011. 'Investigation of the Effects of St John's Wort on Cancer and Drosophila.', AOS-HCI Combined Research Paper, Hwa Chong Institution.

Parameswara Bushan Kumar, Shalini Moses, Basayya Arunkumar, Divya Shree Ramamurthy. 2020. "'Effect of Developmental Toxicity in Drosophila melanogaster on Exposure to Different Food Dyes (Brilliant Blue and Sunset Yellow)"', International Journal of Science and Research (IJSR), 9: 637 - 41.

Sarıkaya, R , Selvi, M , Akkaya, N , Acar, M , Erkoç, F . . 2010. 'Farklı Konsantrasyonlardaki Gıda Boyalarının 
Drosophila melanogaster (mwh x flr)'de Yaşama Yüzdesi Üzerine Etkisi.', Süleyman Demirel Üniversitesi Fen Edebiyat Fakültesi Fen Dergisi, 5: 38-46.

Semerdoken, S. 2012. 'Effects of some synthetic azo food dyes added to foodstuffs on larval mortality and longevity of Drosophila melanogaster's oregon R wild and vestigial mutant strains', Atatürk Üniversitesi Fen Bilimleri Enstitüsü Yayınları.

Topsoy, H. 1990. 'Quantification of synthetic paints added to some sugary foods', Ankara Üniversitesi Sa $\breve{g l l k}$ Bilimleri Enstitüsü Yayınlarl.

Türkoğlu, Şifa, Dilek Benli, and Nihan Şahin. 2015. 'The effects of five food dyes on the longevity of Drosophila melanogaster'.

Uysal H., Semerdoken S. 2011. 'Determination of the effects of Drosophila melanogaster on synthetic food paints on larval toxicity and adult longevity in oregon R line. ', Kafkas Üniversitesi Fen Bilimleri Enstitüsü Dergisi, , 4: 71-87.

Uysal, Handan, S1dıka Genç, and Arif Ayar. 2017. 'Toxic Effects of Chronic Feeding with Food Azo Dyes on Drosophila melanogaster Oregon R', Scientia Iranica, 24: 3081-86.

Vural, N. 2005. General Toxicology (Anadolu Üniversitesi Eczacılık Fakültesi Yayınları).

Yaman, M. 1996. 'Investigation of synthetic dye amount added to some foodstuffs', Gazi Üniversitesi Sosyal Bilimleri Enstitüsü Yayınlarl.

Yentür, G . 1996. 'Investigation of the amount of synthetic dye in cake decorations and some candies provided from Ankara market.', Ankara Üniversitesi Veteriner Fakültesi Dergisi, 43: 479-84.

Zhou, Bei, Li-Jun Wu, Shin-ichi Tashiro, Satoshi Onodera, Fumiaki Uchiumi, and Takashi Ikejima. 2006. 'Silibinin protects rat cardiac myocyte from isoproterenol-induced DNA damage independent on regulation of cell cycle', Biological and Pharmaceutical Bulletin, 29: 1900-05.

Zordan, Mauro, M. Osti, M. Pesce, and R. Costa. 1994. 'Chloral hydrate is recombinogenic in the wing spot test in Drosophila melanogaster', Mutation Research/Genetic Toxicology, 322: 111-16. 